\title{
基于“线上教学” 背景下小学语文的策略研究
}

\author{
陈洁辛 \\ 江西省吉安师范附属小学 \\ DOI:10.32629/jief.v2i4.1228
}

[摘 要] 小学低年级的语文教学注重基础, 这是小学生的启蒙教育时期, 在这一时期, 教师需要不断鼓励小学生, 提倡小学生自主学习, 将 课外阅读和课内知识结合在一起。由于疫情的影响, 小学的教学方式由线下转到线上, 教学方式的转变可能存在很多问题, 因此, 本文将从 “线上教学的基本模式” “线上教学开展的方式”和 “线上教学课后反馈评价”三方面就如何开展线上教学工作进行谈论。

[关键词] 线上教学; 小学语文; 策略研究

中图分类号: G633.3 文献标识码: A

小学低年级段的学生比较依赖自己的感性思维, 因此, 教师在进行 线上教学工作时, 需要积极引导学生发挥自己的自主学习能力, 促使学 生积极参与到线上课堂的讨论中, 激发学生的学习兴趣, 推动学生向前 进步。

\section{1 线上教学的基本模式}

受到疫情的影响, 教学工作不得不从线下转移到线上, 教学的基本 结构与教学模式也发生变化。集体教学模式是教学合作。探讨的一种重 要形式。教师围绕课堂教学, 通过调动学生的集体意识, 让学生共同参 与到课堂中, 有助于更好的掌握教材, 改进创新自己的教学方式, 提高 教学的课堂质量。

\section{2 线上教学开展的方式}

2.1 课前预习

在小学低年级语文教学过程中, 因学生的知识经验和生活经验较少, 教师需要多鼓励学生, 引导学生自主学习, 锻炼他们的思维能力。由于 疫情的缘故, 教师开展线上教学工作。因此, 线上的课前预习必不可少, 教师可以通过故事, 图文, 音乐等方式, 让学生先行了解课堂中需要学 习的知识, 达到较好的课前预习效果。

例如: 学生学习二年级下册古诗二首《村居》和《咏柳》时, 教师 可以鼓励学生先行预习, 通过观看教师发布在钉钉群里的视频, 预习接 下来需要学习的知识内容。对于低年级的学生来说, 教师需要保护学生 探索世界的兴趣和好奇心, 让学生即使在家中也能段炼自己的思维能力。 低年段的小学生是口语向书面语过渡的重要阶段, 在这一重要的阶段, 教师需要重视小学生的识字能力。教师可以布置预习任务, 让学生阅读 古诗二首, 并掌握生词, 理解其意思。教师要以学生喜闻乐见的方式对 学生进行引导, 让其在轻松无压力的氛围下, 获得新知识的内容。

2.2 课中丰富

低年级的学习是最重要的基础内容部分, 教师在开展线上教学工作 时, 需要考虑到学生的年龄以及认知水平, 学生在低年级阶段, 对于语 文还没有一个清晰的概念, 因此, 教师需要做好小学生的语文启蒙教育。 下半年的语文教学工作受到疫情的影响, 从线下转到线上, 对教师的要 求也逐渐提高, 教师需熟练运用信息技术。

例如: 汉字是语文学习的基础, 所以在教学过程中, 教师需要采取 多样化的方式帮助学生识字, 学生尽快掌握汉字, 可以更好的进行接下 来的学习。学生在学习《找春天》时, 教师可以采用游戏、动画、歌曲 等方式, 帮助学生掌握生词。由于是在线上开展教学工作, 教师可以借 助多媒体辅助教学, 教师设计动画, 将汉字拼音生词以及相应的所学内 容放置在同一画面, 学生根据自己学到的汉语, 拼音等知识进行配对。 教师制作课件时, 应符合学生的心理特点, 尽量采用色彩鲜艳的画布, 这不仅可以激发学生的学习兴趣, 而且对于学生来说是一种视觉上的冲
击, 有助于加深学生的印象, 为学习语文打下夯实的基础, 更有助于提 高学生的学习效率。

\section{3 课后复习}

课后及时巩固, 是小学语文教学过程中必不可少的一步, 受到疫情 的影响, 教师无法及时督促学生复习相关知识, 因此需要家长积极配合 教师, 起到督促学生复习的作用。学生完成教师布置的作业后, 拍照上 传到相应的学习平台, 教师批阅后再传回给学生, 并发布正确答案, 学 生订正后, 将错题摘录在错题本上, 在下一次课堂上提出自己存在疑惑 的地方, 由教师解答。

例如: 教师在教学《开满鲜花的小路》时, 可以布置相应的有关任 务, 如抄写课文中的生难词汇, 理解文章的主旨大意, 根据自己的经验 谈谈该篇文章给你的印象? 家长督促学生完成后, 由家长拍照上传到相 应的学习平台, 等待教师的批阅。通过家校联动, 保证在疫情期间学生 的学习效率高, 除此之外, 学生的自主管理能力以及自主学习能力也能 进一步得到提高, 为之后的学习奠定夯实的基础, 培养良好的学习习惯。

\section{3 线上教学课后反馈评价}

教师借助各个学习软件, 在疫情期间开展线上教学工作, 因为是第 一次采取线上教学工作方式, 学生或者教师都存在不适应的地方, 学生 受到年龄的限制, 可能对于教师教授的某些地方存在疑惑, 也存在着教 师讲授过快, 这些问题都需要及时得到解决, 因此家长在学生学习时需 要陪伴在学生身边, 当学生出现疑惑的地方时, 及时反馈给教师, 教师 收到反馈后, 应及时调整自己的教学方式, 考虑学生的学习状况, 实现 高效率的课堂教学。另外, 学生除了线上上课以外, 必要的课外阅读也 不可缺少, 教材中《日积月累》《快乐读书吧》等, 都是十分好的阅读材 料, 有助于培养学生的阅读习惯, 锻炼学生的阅读能力, 从而实现小学 语文的教学目标。

\section{4 结语}

小学语文教学是语文的启蒙期, 因此, 教师在这个阶段需要引导学 生正确学习语文, 从重要时期培养学生的兴趣, 让学生对语文产生学习 的欲望。虽然处在疫情时期, 但学生的语文也需要抓牢, 关键时期的教 学培养十分重要, 这需要教师肩负起教育者的担当。

\section{[参考文献]}

[1]于艳萍. 论中小学语文阅读教学中开展群文阅读的有效途径 [J]. 新课程,2020(37):67.

[2]史羽婷. 培养学生语文综合能力刍议 [N]. 贵州民族 报,2020-08-25(A03).

[3] 徐娜娜.浅析小学语文教学课堂读写训练策略 [J]. 新课 程,2020(34):39. 